\title{
Kepuasan Kerja Dengan Employee Engagement Pada Driver Ojek Online
}

\author{
Dicky Sidarius Halias, Sowanya Ardi Prahara \\ Fakultas Psikologi Universitas Mercu Buana Yogyakarta, Indonesia \\ Sowanya_hara@yahoo.com
}

\begin{abstract}
This study aims to determine the relationship between job satisfaction with employee engagement on online motorcycle taxi drivers who work in Yogyakarta. The hypothesis in this study is that there is a positive relationship between job satisfaction with employee engagement on online motorcycle taxi drivers who work in Yogyakarta. The research subjects were online motorcycle taxi drivers who had worked for at least 3 months totaling 82 people. Taking the subject using purporsive sampling with data collected using the Employee Engagement Scale and Job Satisfaction Scale. Data were analyzed using product moment correlation. Based on the analysis, a correlation value of 0.544 was obtained with $\mathrm{p}=0.000(\mathrm{p}<0.005)$. These results indicate that there is a significant positive relationship between job satisfaction with employee engagement on online motorcycle taxi drivers who work in Yogyakarta. This means that the higher job satisfaction of online motorcycle taxi drivers, the higher the employee engagement of motorcycle taxi drivers online, conversely, the lower the job satisfaction, the lower the employee engagement.
\end{abstract}

Keywords: job satisfaction, employee engagement, motorcycle taxi drivers online

\begin{abstract}
Abstrak
Penelitian ini bertujuan untuk mengetahui hubungan antara kepuasan kerja dengan employee engagement pada driver ojek online yang bekerja di Yogyakarta. Hipotesis dalam penelitian ini adalah terdapat hubungan positif antara antara kepuasan kerja dengan employee engagement pada driver ojek online yang bekerja di Yogyakarta. Subjek penelitian adalah driver ojek online yang sudah bekerja minimal 3 bulan sebanyak 82 orang. Pengambilan subjek menggunakan sampling purporsive dengan data yang dikumpulkan menggunakan Skala Employee Engagement dan Skala Kepuasan Kerja. Data dianalisis menggunakan korelasi product moment. Berdasarkan hasil analisis, diperoleh nilai korelasi sebesar 0.544 dengan $p=0.000(\mathrm{p}<0.005)$. Hasil tersebut menunjukan bahwa terdapat hubungan positif yang signifikan antara kepuasan kerja dengan employee engagement pada driver ojek online yang bekerja di Yogyakarta. Artinya semakin tinggi kepuasan kerja driver ojek online, maka semakin tinggi employee engagement-nya, dan sebaliknya.
\end{abstract}

Kata kunci: kepuasan kerja, employee engagement, driver ojek online

\section{Pendahuluan}

Manusia merupakan mahluk sosial yang mempunyai banyak kebutuhan yang harus dipenuhi untuk kesejahteraan hidupnya. Pemenuhan kebutuhan hidup manusia dapat terealisasikan melalui alat transportasi, salah satunya adalah transportasi darat yang banyak diminati masyarakat (Abbas, 2000) $)^{[1]}$. Menurut Mangifera dan Isa (2017) ${ }^{[13]}$ transportasi darat merupakan sarana utama masyarakat untuk mengefektifkan pekerjaan dan membantu dalam memenuhi kebutuhan sehari-hari. Masyarakat juga sangat tergantung pada transportasi darat untuk menunjang kebutuhan dalam beraktivitas. Selain itu, alasan utama penggunaan transportasi tersebut untuk mempersingkat waktu perjalanan sehingga dapat sampai pada tujuan yang telah ditetapkannya.

Perkembangan teknologi komunikasi yang cukup pesat membawa perubahan perilaku masyarakat dengan kehadiran jasa transportasi darat berbasis aplikasi online. Jasa transportasi data berbasis online sangat berpengaruh bagi masyarakat dalam segala aktifitas secara cepat dan efisien. Lebih lanjut, fenomena transportasi online kini telah menyebar luas ke semua lapisan masyarakat (Giri \& Dewi, 2017) ${ }^{[6]}$. Salah satunya adalah PT Go-Jek Indonesia yang telah beroperasi di 50 kota yang tersebar di Indonesia. Jenis-jenis layanan yang ditawarkan tidak hanya sebatas antar jemput penumpang, namun menawarkan berbagai jenis layanan.

PT Go-Jek Indonesia menawarkan layanan Go-Send yaitu layanan mengantarkan barang, Go-Food yaitu layanan membeli makan (delivery), Go-Tix yaitu layanan membeli tiket bioskop, Go-Message yaitu layanan pijat panggilan, Go- Car yaitu layanan antar jemput menggunakan mobil, dan GoClean yaitu layanan membersihkan ruangan (Go-Jek, 2017) ${ }^{[7]}$. Dijelaskan lebih lanjut bahwa

Diterima Redaksi : 20-01-2020 | Selesai Revisi : 27-01-2020 | Diterbitkan Online : 28-01-2020 
keunggulan dan berbagai layanan yang ditawarkan Go-Jek telah menyebar luas ke semua lapisan masyarakat salah satunya di Yogyakarta. Peluang bisnis di Yogyakarta sangat menjanjikan yang berdampak pada penghasilan dari pelaku usaha yang ada di sana, hal tersebut karena Yogyakarta merupakan kota pariwisata, pelajar, dan tingkat konsumtif yang tinggi sehingga setiap pelaku usaha memiliki kesempatan untuk mencapai kesuksesan. Salah satunya, bisnis transportasi online yaitu Gojek yang saat ini dihadapkan persaingan yang ketat dengan kompetitornya (Aria, 2018) ${ }^{[4]}$.

Persaingan bisnis transportasi darat berbasis online sudah semakin kompetitif membuat perusahaan dituntut untuk mengoptimalkan unsur manusia yang dimilikinya yaitu driver Go-Jek (Mangifera \& Isa, 2017) ${ }^{[13]}$. Pengoptimalan yang tepat dapat mewujudkan harapan PT Go-jek Indonesia yaitu karyawan sebagai ujung tombak dalam menentukan kemajuan perusahaan akan menjadi tumpuan ke depannya dalam menghadapi persaingan pasar (Go-Jek, 2017) ${ }^{[7]}$. Oleh karena itu, untuk mewujudkan harapan tersebut, karyawan terlebih dahulu diharuskan memiliki engagement agar dapat terikat secara fisik, kognitif, dan emosional dalam bekerja, sehingga terfokus pada tujuan dan kesuksesan perusahaan (Kahn dalam Albrecht, 2010) ${ }^{[2]}$.

Employee engagement merupakan pandangan hidup positif yang membawa karyawan pada keadaan pemenuhan diri untuk menumbuhkan rasa memiliki dan pada akhirnya karyawan merasa sulit melepaskan diri dengan pekerjaannya (Schaufeli, Salanova, Gonzalez \& Bakker, 2002) ${ }^{[16]}$. Lebih lanjut dijelaskan bahwa employee engagement terbagi dalam tiga aspek yaitu aspek vigor (semangat) merupakan tingginya tingkat kekuatan dalam bekerja, keinginan untuk berusaha dengan sungguhsungguh menjalani pekerjaan, dan gigih menghadapi kesulitan dalam pekerjaannya. Aspek dedication (dedikasi) merupakan suatu perasaan yang penuh makna, antusias, inspirasi, kebanggaan dan menantang dalam melakukan pekerjaan. Aspek absorption (penghayatan) merupakan adanya konsentrasi, minat mendalam, tenggelam dalam pekerjaan, waktu terasa berlalu begitu cepat dengan begitu karyawan akan sulit melepaskan diri dari pekerjaan sehingga dapat melupakan segala sesuatu di sekitarnya.

Karyawan yang engaged cenderung loyal terhadap pekerjaannya dan bersedia bertahan dalam jangka waktu yang panjang. Tidak hanya bertahan, tetapi juga berkontribusi pada keuntungan perusahaan dengan bekerja secara produktif dan berkualitas (Triwijanarko, 2017) ${ }^{[19]}$. Menurut Kaswan (2017) ${ }^{[10]}$ karyawan yang engaged lebih bahagia dalam bekerja dan cenderung menceritakan hal positif tentang organisasinya kepada orang lain. Menurut Robinson, Perryman, dan Hayday (2004) ${ }^{[15]}$ employee engagement akan membuat karyawan memiliki kesadaran terhadap bisnis untuk memberikan upaya terbaik dalam meningkatkan kinerja. Karyawan secara sadar akan mengikat dirinya dalam pekerjaan dengan berkomitmen secara fisik, kognitif dan emosional untuk memberikan usaha terbaiknya melebihi apa yang dijadikan target perusahaan (Kahn dalam Albercht, 2010) ${ }^{[2]}$.

Akan tetapi pada kenyataannya, menurut Riset Dale Carnegie Indonesia yang menyertakan 1.200 karyawan menunjukan bahwa hanya 25\% karyawan yang engaged, 9\% disengaged, dan 66\% partially-engaged. Karyawan partially-engaged, tentunya mengkhawatirkan karena bisa berpindah ke disengaged jika perusahaan tidak lekas mengambil langkah antisipasi. Selain itu, survey yang dilakukan AON Hewitt (2012) ${ }^{[3]}$ tentang employee engagement di seluruh dunia yang mencakup 6.7 juta karyawan pada lebih dari 2.900 perusahaan menunjukkan penurunan tingkat enaged karyawan dari 60\% di tahun 2009 menjadi 56\% di tahun 2010. Data tersebut memperlihatkan bahwa masih banyak karyawan yang belum terlibat dalam pekerjaannya, sehingga sangat disayangkan karena peran unsur manusia di perusahaan sangat penting untuk dapat meraih kesuksesan perusahaan.

Employee engagement berperan penting dalam lingkup bisnis karena menjadi salah satu langkah yang berdampak pada hasil bisnis dengan bertahannya karyawan di tempat kerja (Kahn dalam Albercht, $2010)^{[2]}$. Hal ini juga dapat dijumpai pada driver Go-Jek yang bekerja dengan penuh dedikasi, maka akan lebih berkomitmen dan terikat dengan pekerjaannya (Aria, 2018) ${ }^{[4]}$. Menurut Schaufeli, dkk., $(2002)^{[16]}$ dedikasi merupakan bagian penting dari employee engagement. Lebih lanjut, seseorang (driver Go-Jek) berdedikasi akan menjadikan pekerjaannya sebagai pengalaman berharga, menginspirasi dan menantang, sehingga jika terdapat berbagai kesulitan (seperti mengantar pesanan di waktu hujan maupun penumpang yang tidak mencapai target), maka seseorang (driver Go-Jek) tidak akan patah semangat dan terus bekerja dengan pelayanan terbaiknya untuk tempatnya bekerja. Schaufeli, dkk., (2002) $)^{[16]}$ juga menyatakan bahwa employee engagement berperan penting sebagai pemicu terjadinya vigor, dimana seseorang (driver Go-Jek) yang memiliki aspek tersebut merasakan kesenangan terhadap setiap pekerjaannya, sehingga terhindar dari kelelahan dalam bekerja. Lebih 
lanjut, seseorang (driver Go-Jek) juga akan lebih menunjukan absorption-nya dengan berkonsentrasi saat bekerja (membawa kendaraan) dan merasa waktu begitu cepat berlalu, sehingga tenggelam dalam pekerjaan dan sulit meninggalkan pekerjaannya. Pandangan tersebut menunjukkan bahwa employee engagement membuat karyawan dapat berkomitmen, antusias, dan menunjukan prestasi kerja untuk keberlangsungan bisnis yang semakin kompetitif (Robinson, dkk., 2004) ${ }^{[15]}$.

Menurut Vazirani (2007) ${ }^{[20]}$ salah satu faktor yang mempengaruhi employee engagement adalah kepuasan kerja.hal ini dikuatkan oleh Kaswan (2017) ${ }^{[10]}$ bahwa kepuasan kerja secara signifikan dapat mempengaruhi employee engagement. Hal tersebut didukung berdasarkan hasil penelitian yang dilakukan oleh Lumbantoruan (2015) ${ }^{[12]}$ bahwa terdapat hubungan positif antara kepuasan kerja dengan employee engagement.

Kepuasan kerja merupakan cara karyawan merasakan pekerjaannya dengan generalisasi sikap terhadap pekerjan yang didasarkan atas aspek-aspek pekerjaannya yang bermacam-macam (Wexley \& Yukl, 2003) ${ }^{[21]}$. Kaswan (2017) ${ }^{[10]}$ mendefinisikan kepuasan kerja sebagai keadaan emosi positif maupun emosi negatif yang berasal dari penilaian karyawan tentang seberapa baik pekerjaan memberikan hal yang dinilai penting. Kepuasan kerja juga merupakan perasaan karyawan bahwa bekerja sebagai hal menyenangkan yang memberikan pertumbuhan karier, perkembangan peluang dalam bekerja, dan membuat karyawan untuk membantu dalam menyeimbangkan pekerjaan dan kehidupan pribadi (Robinson, dkk., 2004).

Menurut Wexley dan Yukl (2003) ${ }^{[21]}$ kepuasan kerja terbagi dalam tiga aspek yaitu aspek pekerjan merupakan perasaan serta sikap karyawan dalam memandang suatu pekerjaan. Aspek kompensasi merupakan sejumlah upah yang diterima karyawan sesuai dengan harapannya. Aspek pengawasan merupakan pandangan karyawan bahwa pengawas mampu berprilaku bijaksana dengan memberikan bantuan serta dukungan perilaku ketika dibutukan oleh karaywannya.

Menurut As'ad (2004) ${ }^{[5]}$ kepuasan kerja merupakan perasaan karyawan dalam memandang pekerjaannya, karyawan akan terpuaskan dengan adanya kesesuaian antara kemampuan, keterampilan dan harapan dengan pekerjaan yang dihadapi. Kepuasan kerja memiliki korelasi dengan berbagai variabel, salah satunya berkorelasi dengan variabel employee engagement. Apabila karyawan merasakan adanya kepuasan kerja, maka karyawan dapat melaksanakan pekerjaan dengan emosi positif yaitu perasaan senang dan bersemangat untuk menjalani pekerjaan sehingga akan menunjukan rasa engaged-nya (Kaswan, 2017) ${ }^{[10]}$. Karyawan yang engaged cenderung loyal dan bersedia bertahan dalam jangka waktu yang panjang. Tidak hanya bertahan, tetapi juga berkontribusi pada keuntungan perusahaan, serta bekerja secara produktif dan berkualitas (Triwijanarko, 2017) ${ }^{[19]}$. Hal tersebut menjadikan kepuasan kerja secara konsisten berkaitan dengan seberapa besar employee engagement yang dimiliki karyawan (Kaswan, 2017) ${ }^{[10]}$. Hal ini juga didukung oleh hasil penelitian Karangan (2015) ${ }^{[9]}$ yang mengungkapkan bahwa kepuasan kerja memberikan sumbangan efektif sebesar $60.8 \%$ terhadap employee engagement.

Berdasarkan uraian latar belakang masalah di atas, menunjukkan bahwa diperlukan sebuah strategi dari PT Go-Jek Indonesia untuk keberhasilan karyawan atau driver Go-jek yang bekerja di Yogyakarta dalam melaksanakan pekerjaan pada bisnis transportasi darat berbasis online, yaitu dengan mengembangkan penilaian positif terhadap seberapa jauh pekerjaan secara keseluruhan dapat memuaskan kebutuhannya. Driver Go-Jek yang terpuaskan atas kebutuhannya akan memiliki kesadaran bisnis sehingga dapat terlibat secara penuh untuk menunjukan prestasi kerja dan mempertahankan dirinya di tempat kerja. Oleh karena itu, driver Go-Jek akan mewujudkan harapan perusahaan yaitu dapat menjadi tumpuan ke depannya untuk menghadapi persaingan pasar di Yogyakarta yang semakin kompetitif, maka rumusan masalah dalam penelitian ini sebagai berikut: "Apakah terdapat hubungan antara kepuasan kerja dengan employee engagement pada driver Go-Jek yang bekerja di Yogyakarta?"

\section{Metode Penelitian}

Subjek pada penelitian ini adalah driver Go-Jek yang bekerja di Yogyakarta berjumlah 82 orang. Pengambilan subjek dalam penelitian ini menggunakan sampling purporsive. Menurut Sugiyono (2016) sampling purporsive adalah teknik penentuan sampel dengan pertimbangan tertentu atau menetapkan ciri-ciri khusus yang sesuai dengan tujuan penelitian. Adapun kriteria subjek penelitian adalah driver Go-Jek yang sudah bekerja minimal tiga bulan. 
Metode pengumpulan data menggunakan skala yang mengacu pada model Likert. Aitem-aitem dalam skala ini dibagi ke dalam satu kelompok, yaitu kelompok favorable. Adapun skala yang digunakan adalah Skala Employee Engagement dan Skala Kepuasan Kerja. Skala Employee Engagement disusun oleh peneliti berdasarkan teori dari Schaufeli, dkk. (2002) ${ }^{[16]}$. Skala Employee Engagement terdiri dari 14 aitem dengan koefisien aitem total bergerak dari rentang 0,266-0,589, dengan nilai reliabilitas sebesar 0,780. Sedangkan Skala Kepuasan Kerja disusun peneliti berdasarkan teori dari Wexley dan Yukl $(2003)^{[21]}$. Skala ini terdiri dari 13 aitem dengan koefisien aitem total bergerak dari rentang 0,312 - 0,545, dengan nilai reliabilitas sebesar 0,790. Metode analisis data menggunakan Teknik korelasi product moment.

\section{Hasil dan Pembahasan}

Uji normalitas dilakukan untuk mengetahui sebaran yang diukur memiliki sebaran normal atau tidak. Uji normalitas menggunakan Teknik analisis model one sample Kolmogorov-Smirnov (KS-Z). Hasil uji normalitas pada variabel employee engagement diperoleh nilai $\mathrm{KS}-\mathrm{Z}=0,081$ dengan nilai signifikansi $\mathrm{p}=0,200$ dan variabel kepuasan kerja diperoleh nilai $\mathrm{KS}-\mathrm{Z}=0,88$ dengan nilai signifikansi $\mathrm{p}=0,174$. Data tersebut menunjukan bahwa skor variabel employee engagement dan variabel kepuasan kerja driver Go-Jek yang bekerja di Yogyakarta terdistribusi secara normal.

Hasil uji linieritas variabel employee engagement dan kepuasan kerja diperoleh nilai koefisien linier $\mathrm{F}=40,067$ dengan taraf signifikansi $\mathrm{p}=0,000$ berarti hubungan antara employee engagement dan kepuasan kerja driver Go-Jek yang bekerja di Yogyakarta merupakan hubungan yang linier.

Pengujian hipotesis dalam penelitian ini menggunakan analisis korelasi product moment (pearson correlation), yang dikembangkan oleh Karl Pearson (Sugiyono, 2016) ${ }^{[17]}$. Hasil analisis korelasi product moment (pearson correlation) diperoleh koefisien korelasi $\left(\mathrm{r}_{\mathrm{Xy}}\right)=0,544$ dengan nilai signifikansi $\mathrm{p}=0.000(\mathrm{p}<0,05)$ yang berarti ada hubungan positif antara employee engagement dan kepuasan kerja driver Go-Jek yang bekerja di Yogyakarta. Nilai korelasi antara employee engagement dan kepuasan kerja driver Go-Jek yang bekerja di Yogyakarta sebesar 0,544 termasuk koefisien nilai korelasi yang kuat (Sugiyono, 2015) ${ }^{[17]}$.

Penelitian ini bertujuan untuk mengetahui hubungan antara kepuasan kerja dengan employee engagement pada driver Go-Jek di Yogyakarta. Hasil analisis product moment menunjukkan koefisien korelasi (rxy) sebesar $0.839(\mathrm{p}=0.000)$. Hal ini menunjukkan bahwa terdapat hubungan positif yang signifikan antara kepuasan kerja dengan employee engagement pada driver Go-Jek. Artinya semakin tinggi kepuasan kerja maka semakin tinggi pula employee engagement, sebaliknya semakin rendah kepuasan kerja maka semakin rendah pula employee engagement.

Diterimanya hipotesis dalam penelitian ini mengungkapkan bahwa kepuasan kerja menjadi faktor yang dapat mempengaruhi employee engagement. Hal tersebut juga mendukung hasil penelitian Lumbantoruan $(2015)^{[12]}$ yang mengungkapkan bahwa terdapat hubungan antara kepuasan kerja dengan employee engagement. Selain itu, hasil penelitian Karangan (2015 $)^{[9]}$ juga mengungkapkan bahwa terdapat huungan hubungan positif yang signifikan antara kepuasan kerja dengan employee engagement.

Menurut As'ad (2004) kepuasan kerja merupakan salah satu aspek psikologis yang mencerminkan perasaan karyawan terhadap pekerjaannya, karyawan akan merasa puas dengan adanya kesesuaian antara kemampuan, keterampilan dan harapannya dengan pekerjaan yang dihadapi. Menurut Wexley dan Yukl (2003) karyawan yang terpuaskan akan termotivasi untuk terlibat lebih jauh dengan pekerjaannya sehingga terciptalah kondisi kerja yang menyenangkan. Lebih lanjut, kepuasan kerja juga harus memenuhi aspek tertentu agar dapat berpengaruh baik bagi karyawan maupun perusahaan. Tiga aspek dalam kepuasan kerja yaitu pekerjaan, kompensasi, dan pengawasan.

Aspek pekerjaan merupakan perasaan serta sikap karyawan dalam memandang suatu pekerjaannya (Wexley \& Yukl, 2003) ${ }^{[21]}$. Menurut Hezberg (dalam Munandar, 2004) ${ }^{[14]}$ karyawan yang puas terhadap pekerjaan akan mempunyai motivasi untuk bekerja dan senang dalam melakukan tugastugasnya. Hal tersebut membentuk rasa engaged yang membuat karyawan berusaha dengan sungguhsungguh dalam menyelesaikan pekerjaan, gigih menghadapi kesulitan, dan merasa senang perhatiannya tersita oleh pekerjaan (Schaufeli, dkk., 2002) ${ }^{[16]}$. Dikuatkan oleh Susilo dan Prahara $(2019)^{[18]}$ apabila pekerjaan dirasa memberikan manfaat positif bagi karyawan yang telah berkeluarga maka akan berpengaruh pada engagement-nya terhadap pekerjaan yang dilakukan. Hal ini didukung 
berdasarkan data lapangan yang menunjukan peraturan yang diberikan perushaan memudahkan subjek untuk bekerja dan subjek merasa senang dengan pekerjaan yang dilakukannya karena sesuai dengan bakat yang dimiliki, sehingga subjek tetap fokus menggantar costumer walaupun waktu sudah larut malam dan waktu terasa berlalu begitu cepat karena menikmati pekerjaan ini.

Karyawan akan menikmati pekerjaannya ketika menilai sejumlah upah yang diterima sesuai dengan harapannya yaitu melalui aspek kompensasi (Wexley \& Yukl, 2003) ${ }^{[21]}$. Menurut Handoko (2002) $)^{[8]}$ kompensasi yang diberikan perusahaan akan mendorong karyawan untuk berprestasi lebih baik, sehingga menimbulkan imbalan ekonomi (karyawan lebih produktif). Imbalan ekonomi yang diterima dapat menimbulkan rasa engaged, maka karyawan akan menunjukan kesadaran pada konteks bisnis, meningkatkan kinerja dan lebih berkomitmen dalam menyelesaikan tugas-tugasnya (IES dalam Robbinson, dkk., 2004) ${ }^{[15]}$. Hal ini didukung berdasarkan data lapangan yang menunjukan bahwa pendapatan sebagai driver Go-jek sesuai dengan beban kerja yang diterima subjek dan subjek diberikan bonus yang memuaskan dengan apa yang dilakukannya, sehingga subjek melakukan pekerjaan dengan sungguh-sungguh dan ketika kesulitan menghadapi penumpang membuat subjek merasa lebih tertantang pada pekerjaan.

Pengawasan juga menjadi salah satu aspek penting yaitu pandangan karyawan bahwa pengawas mampu memberikan bantuan ketika dibutuhkan (Wexley \& Yukl, 2003) ${ }^{[21]}$. Lebih lanjut dijelaskan bahwa karyawan yang mendapatkan bantuan dari pengawas akan bekerja dengan penuh semangat, aktif, berprestasi dan bahagia. Semangat karyawan menunjukkan rasa engaged-nya dengan melakukan upaya bersifat sukarela, yaitu memberikan usaha terbaik melebihi target perusahaan (Robinson, dkk., 2004) ${ }^{[15]}$. Selain itu karyawan yang bahagia diasumsikan akan memiliki antusiasme dalam menjalankan pekerjaan dan semangat dalam bekerja, dengan demikian berarti terdapat rasa work engagement pada diri karyawan (Kesumaningsari \& Simarmata, 2014) ${ }^{[11]}$. Hal ini didukung berdasarkan data lapangan yang menunjukkan bahwa perusahaan dapat memberikan solusi yang tepat, ketika subjek mendapatkan permasalahan di lapangan dan perusahaan mengakui prestasi yang telah subjek capai dengan memberikan bonus tepat waktu, sehingga sehingga subjek tetap bekerja dengan semangat selama seharian penuh mengantar penumpang dan mampu menjaga konsentrasi saat berkendara walau jalan sedang dalam keadaan macet atau ramai.

Kaswan (2017) ${ }^{[10]}$ menyatakan apabila karyawan merasakan adanya kepuasan kerja di dalam dirinya, maka akan melaksanakan pekerjaan dengan emosi positif yaitu bersemangat menjalani tugas-tugas yang diberikan sehingga karyawan akan menunjukan rasa engaged-nya. Karyawan yang engaged cenderung loyal terhadap pekerjaanya dan bersedia bertahan dalam jangka waktu yang panjang (Triwijanarko, 2017) ${ }^{[19]}$. Selain itu karyawan yang merasakan pekerjaan yang dilakukan

\section{Kesimpulan}

Berdasarkan hasil penelitian dan pembahasan di atas, maka dapat disimpulkan bahwa terdapat hubungan yang positif antara kepuasan kerja dengan employee engagement pada driver Go-Jek yang bekerja di Yogyakarta.

\section{Daftar Rujukan}

[1] Abbas, S. 2000. Manajemen transportasi. Jakarta : Ghalia Indonesia.

[2] Albrecht, S. L. 2010. Handbook of employee engagement : perspectives, issues research and practice. United Kingdom : Edward Elgar Publishing Ltd.

[3] AON Hewitt. 2012. Trends in global employee engagement. https://www.aon.com/attachments/thoughtleadership/Trends_Global_Employee_Engagement_Final.pdf diakses pada tanggal 20 Juni 2018.

[4] Aria, P. 2018. Uber tersingkir, persaingan grab dan go-jek makin sengit. Diakses tanggal 20 Januari 2018 dari https://katadata.co.id/berita/2018/03/27/uber- tersingkir persaingan-grab-dan-go-jek-makin-sengit.

[5] As'ad, M. 2004. Psikologi industri : seri ilmu sumber daya manusia edisi keempat. Yogyakarta : Liberty.

[6] Giri, P.C., \& Dewi, M.H.U. 2017. Analisis faktor-faktor yang mempengaruhi pendapatan driver Go-jek di kota Denpasar, Bali. E-Jurnal Ekonomi Pembangunan Universitas Udayana, 6(6), 948-975.

[7] Gojek. 2019. Gojek Jogja: Satu aplikasi untuk beragam solusi. Diakses pada 10 Desember 2019 dari https://www.gojek.com/blog/gojek/jogja/

[8] Handoko, T. H. 2012. Manajemen sumber daya manusia \& sumber daya manusia. Yogyakarta : BPFE. 
[9] Karangan, C. R. 2015. Pengaruh kepuasan kerja terhadap employee engagement teller di pt. bsnk negara indonesia cabang bandung. Skripsi. Diakses tanggal 20 Januari 2018 dari https://repository.widyatama.ac.id/xmlui/handle/123456789/ 7778.

[10] Kaswan. 2017. Psikologi industri dan organisasi. Bandung : Alfabeta.

[11] Kesumaningsari, N. P. A., \& Simarmata, N. 2014. Konflik kerja-keluarga dan work engagement karyawati Bali pada bank di Bali. Psikologi Udayana, 1(3), 493-506.

[12] Lumbantoruan, L. P. M. 2015. Hubungan antara kepuasan kerja dengan employee engagement karyawan tetap non manajerial pad apt metrocom global solusi. Skripsi. Diakses tanggal 20 Januari 2018 dari http://lib.ui.ac.id/file?file=pdf/abstrak /id_abstrak-20413724.pdf.

[13] Magnifera, L., \& Isa, M. 2017. Komitmen dan kinerja driver ojek online di kota Surakarta. Prosiding Seminar Nasional Riset Manajemen \& Bisnis 2017 "Perkembangan Konsep dan Riset E-Business di Indonesia.

[14] Munandar, A. S. 2004. Psikologi industri dan organisasi. Jakarta : Universitas Indonesia.

[15] Robinson, D., Perryman, S., \& Hayday. 2004. The drivers of employee engagement report 408. Brington: Institude for Employement Studies.

[16] Schaufeli, W.B., Salanova, M., González-Romá. V., \& Bakker, A.B. 2002. The measurement of engagement and burnout: A confirmatory factor analytic approach. Journal of Happiness Studies, 2(3), 71-92.

[17] Sugiyono. 2016. Metode penelitian kuantitatif, kualitatif, dan R\&D. Bandung: Alfabeta.

[18] Susilo, D.F.Z., \& Prahara, S.A. 2019. Work-family enrichment dan work engagement pada karyawan yang sudah menikah. Mediapsi, 5(2), 108-116.

[19] Triwijanarko, R. 2017. Hanya 25\% karyawan millennials yang loyal dengan kantornya. https://marketeers.com/karyawan-milenial-yang-loyal/ diakses 8 Juni 2018.

[20] Vizarani, N. A. 2007. Employee engagement working paper for the sies college of management studies.

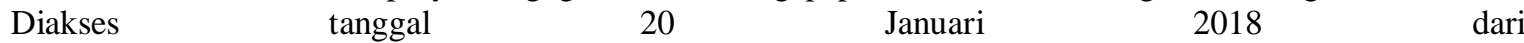
http://www.siescoms.edu/images/pdf/reserch/working_papers/employyee_enga gement.pdf.

[21] Wexley, K. N. \& Yukl, G. A. 2003. Perilaku organisasi dan psikologi personalia. Jakarta : Bina Aksara. 